\title{
Chemical and physical investigations of historic mortars in St. John's Church (Cesis, Latvia)
}

\author{
Inta Kirilovica ${ }^{1}$, Margarita Karpe ${ }^{2}$ \\ Institute of Silicate Materials, Faculty of Material Science and Applied Chemistry, \\ Riga Technical University, Paula Valdena Street 3/7, LV-1048, Riga, Latvia

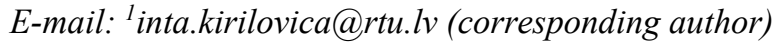

\begin{abstract}
This paper deals with the stone material investigation of St. John's Church, located in Cesis, the city in central region of Latvia. Following aspects were considered - chemical, physical and granulometrical characterization of historic mortars, as well as the level of soluble salts in the masonry. The chemical and physical properties of the historical mortars were characterized by visual observation, granulometric analysis, classical wet chemical analysis, XRD, SEM and hydro tests. The results showed that the historic mortars are based on two types of weakly hydraulic lime - calcitic and dolomitic - with brick dust additive. The main crystallized salt in the object was $\mathrm{KNO}_{3}$. The aim of the investigation was to provide compatibility of restoration materials and sustainability of the ancient building.
\end{abstract}

Keywords: Medieval church, mortar, chemical analysis, restoration.

\section{Introduction}

St. John's Church is one of the oldest Medieval heritage buildings in Latvia. It was built by Livonian Order in the $13^{\text {th }}$ century, but have been rebuilt many times (see Figure 1).

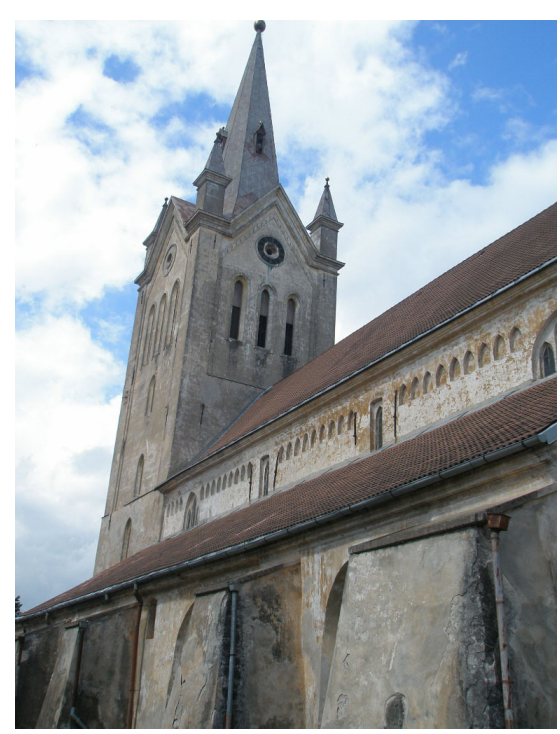

Figure 1. Cesis St. John's Church (2018)

The choice of modern restoration materials must be based on the research data of historical ones (Krage \& Vitina, 2005; Palomo, Blanco-Varela, Martinez-Ramirez, Puertas, \& Fortes, 2004). The fundamental requirements of mortar for restoration are similar composition and characteristics (hydraulic properties, porosity, grain size distribution of filler, free water absorption, etc.) (Ashurst, 1988). Historically in Latvia the medium hydraulic dolomitic lime mortar has been used in main part of cases (Krage \& Vitina, 2005 Kiriloviča, Gulbe, Vìtiņa, \& Igaune-Blumberga, 2015).

(C) 2019 Authors. Published by VGTU Press. This is an open-access article distributed under the terms of the Creative Commons Attribution (http://creativecommons.org/licenses/by/4.0/) License, which permits unrestricted use, distribution, and reproduction in any medium, provided the original author and source are credited. 
Hydraulic properties are of great importance, providing mechanical strength and water resistance. Lack of hydraulic properties of the contemporary high-purity limes without any additives can result in the leaching of the lime binder. Based on the knowledge of the impact of hydraulic components, historically the brick dust was added to mortars in order to provide the necessary content of active $\mathrm{SiO}_{2}$ and $\mathrm{Al}_{2} \mathrm{O}_{3}$ for improvement of hydraulic properties (ability to harden with water, increased mechanical strength and moisture resistance) of lime mortars (Černý, Kunca, Tydlitát, Drchalová, \& Rovnaníková, 2006; Teutonico, McCaig, Burns, \& Ashurst, 1993; Nežerka et al., 2014). Research has proven that moderately fired brick dust (firing temperature $450-800{ }^{\circ} \mathrm{C}$ ) can increase the hydraulicity of a mortar about two times (Dzene, 2011). Hydraulic components (brick dust, metakaolinite, 5-10\% cement additive) must be added to lime mortars that are used for façade construction to provide hydraulicity (Pacheco-Torgal, Faria, \& Jalali, 2012).

\section{Experimental procedure}

The experimental research included investigation of ten mortar samples from St. John's Church - two from tower (LA1 and LA2) and eight from the façade around the building. Laboratory investigations included:

1. Full chemical analysis of mortars (Teutonico, 1988).

The chemical composition of historical mortars was detected according to LVS EN 196-2:2013 by classical (wet) chemical analysis. The loss of ignition was determined at $400{ }^{\circ} \mathrm{C}$ and $1000{ }^{\circ} \mathrm{C}$ temperatures. For dissolving the samples $\mathrm{H}_{2} \mathrm{SO}_{4}$ and $\mathrm{HF}$ were used. Soluble $\mathrm{SiO}_{2}$ and $\mathrm{Al}_{2} \mathrm{O}_{3}$ were determined by sedimentation, $\mathrm{CaO}$ and $\mathrm{MgO}-$ by complexonometric titration, $\mathrm{Fe}_{2} \mathrm{O}_{3}$ - by photocolorimetry, $\mathrm{Na}_{2} \mathrm{O}$ and $\mathrm{K}_{2} \mathrm{O}$ - by flame photometry.

2. Grain size distribution.

The granulometric analysis was done according to LVS EN 933-1:2012 by dissolving the binder with 10\% $\mathrm{HCl}$ and sieving the washed aggregate through gradual finer sieves

3. X-ray diffraction analysis (XRD) - by using X-ray diffractometer Rigaku Ultima ${ }^{+}$with $\mathrm{CuK}_{\alpha}$ radiation at a scanning interval $5-60^{\circ}(2 \theta)$ and speed $2^{\circ} / \mathrm{min}$.

4. Hydro tests (water absorption, porosity, density) - according to EN 1936:1998 E with 5 parallel measurements.

5. Scanning electron microscopy (SEM) - by using Hitachi TableTop Microscope TM3000, Compo mode.

6. Soluble salt analysis - semi-quantitative method by using test stripes (dissolution state $-1 \mathrm{~g}$ of mortar in $20 \mathrm{ml}$ of water).

\section{Results and discussion}

The results of chemical analyses of historical mortars (Table 1) showed that in the building two types of binder were used - dolomitic lime for the façade and calcitic lime for the tower (samples LA1 and LA2). From the same results such data as modulus of hydraulicity, binder to aggregate ratio and the initial composition of binder was calculated (Table 2). In the Table 1 and Table 2 seven representative samples of all investigated samples were included.

The binder to aggregate ratio of the mortars was $1: 2.1-5.3$, and for dolomitic lime mortars the ratio $\mathrm{CaO}: \mathrm{MgO}$ was 1.19-2.67. The modulus of hydraulicity (Eq. (1)) of tested mortars was approximately 6-8 which shows the weak hydraulic properties of binders, according to Vicat classification (Divet, 2010).

$$
m=\frac{\mathrm{CaO}+\mathrm{MgO}}{\mathrm{SiO}_{2}+\mathrm{Al}_{2} \mathrm{O}_{3}+\mathrm{Fe}_{2} \mathrm{O}_{3}} .
$$

Some samples (LA4 and LA5) contained also additives of coarse glass particles. Fine glass powder is known to act as pozzolan similarly as brick dust (see Figure 2) (Idir, Cyr, \& Tagnit-Hamou, 2011), although in this case it acts more as a filler because of it's coarse size. Presence of biological fibre and wood chips were detected in samples LA6 and LA7, respectively.

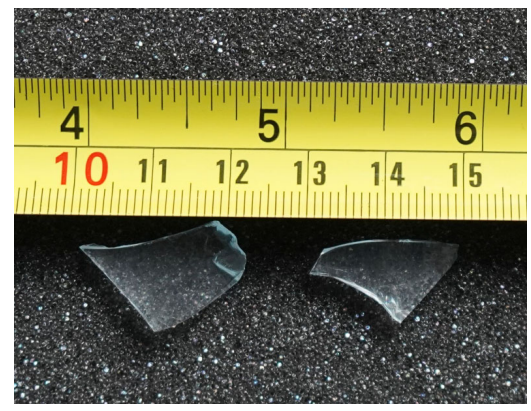

Figure 2. Coarse glass particles in the mortar sample 
Table 1. Chemical composition of historic mortars, mass \%

\begin{tabular}{|c|c|c|c|c|c|c|c|c|}
\hline Component $\quad$ Sample & $\begin{array}{l}\text { LA1 } \\
\text { (tower) }\end{array}$ & $\begin{array}{l}\text { LA2 } \\
\text { (tower) }\end{array}$ & LA4 & LA5 & LA6 & LA7 & LA10 & $\begin{array}{c}\text { Error, } \pm \\
\text { absolute \% }\end{array}$ \\
\hline $\begin{array}{c}\text { Loss of ignition: } \\
400^{\circ} \mathrm{C} \\
1000^{\circ} \mathrm{C}\end{array}$ & $\begin{array}{c}1.22 \\
11.34\end{array}$ & $\begin{array}{c}2.68 \\
14.50\end{array}$ & $\begin{array}{c}3.83 \\
17.22\end{array}$ & $\begin{array}{l}3.08 \\
9.91\end{array}$ & $\begin{array}{l}4.32 \\
9.48\end{array}$ & $\begin{array}{l}6.24 \\
9.73\end{array}$ & $\begin{array}{c}7.07 \\
16.36\end{array}$ & $\begin{array}{l}0.5 \\
0.5\end{array}$ \\
\hline $\begin{array}{l}\text { Insoluble residue in } \\
\mathrm{HCl} \text { (aggregate: sand) }\end{array}$ & 68.86 & 60.85 & 57.52 & 67.25 & 69.66 & 64.75 & 50.52 & 0.5 \\
\hline $\mathrm{CaO}$ & 14.38 & 15.07 & 11.92 & 11.90 & 7.73 & 8.32 & 14.47 & 0.5 \\
\hline $\mathrm{MgO}$ & 1.03 & 3.64 & 5.74 & 4.45 & 5.30 & 7.01 & 7.54 & 0.2 \\
\hline Soluble $\mathrm{SiO}_{2}$ & 0.47 & 0.44 & 1.03 & 0.84 & 0.47 & 0.64 & 0.62 & 0.2 \\
\hline $\mathrm{Al}_{2} \mathrm{O}_{3}$ & 1.20 & 1.27 & 1.17 & 0.80 & 0.67 & 0.71 & 1.64 & 0.2 \\
\hline $\mathrm{Fe}_{2} \mathrm{O}_{3}$ & 0.64 & 0.60 & 0.68 & 0.54 & 0.48 & 0.63 & 0.50 & 0.05 \\
\hline Total: & 99.14 & 99.05 & 99.11 & 98.77 & 98.11 & 98.03 & 98.72 & - \\
\hline $\mathrm{CaO} / \mathrm{MgO}$ & 13.96 & 4.14 & 2.08 & 2.67 & 1.46 & 1.19 & 1.92 & - \\
\hline $\begin{array}{l}\text { Binder to aggregate } \\
\text { ratio }\end{array}$ & $1: 3.9$ & $1: 2.9$ & $1: 2.8$ & $1: 3.6$ & $1: 4.8$ & $1: 3.7$ & $1: 2.1$ & - \\
\hline Type of binder & $\begin{array}{l}\text { Calcitic } \\
\text { lime }\end{array}$ & $\begin{array}{l}\text { Calcitic } \\
\text { lime }\end{array}$ & $\begin{array}{l}\text { Dolomiti } \\
\text { c lime }\end{array}$ & $\begin{array}{l}\text { Dolomiti } \\
\text { c lime }\end{array}$ & $\begin{array}{l}\text { Dolomiti } \\
\text { c lime }\end{array}$ & $\begin{array}{l}\text { Dolomiti } \\
\text { c lime }\end{array}$ & $\begin{array}{l}\text { Dolomiti } \\
\text { c lime }\end{array}$ & - \\
\hline $\begin{array}{l}\text { Modulus of hydraulicity } \\
\text { m (Eq. (1)) }\end{array}$ & 6.67 & 8.09 & 6.13 & 7.50 & 8.04 & 7.74 & 7.97 & - \\
\hline
\end{tabular}

Table 2. Calculated initial composition of binder in historical mortars from chemical analysis, mass \%

\begin{tabular}{|c|c|c|c|c|c|c|c|}
\hline $\begin{array}{c}\text { Sample } \\
\text { Component }\end{array}$ & $\begin{array}{c}\text { LA1 } \\
\text { (tower) }\end{array}$ & $\begin{array}{c}\text { LA2 } \\
\text { (tower) }\end{array}$ & LA4 & LA5 & LA6 & LA7 & LA10 \\
\hline $\mathrm{CaO}$ & 81.15 & 71.69 & 58.03 & 64.22 & 52.76 & 48.06 & 58.42 \\
\hline $\mathrm{MgO}$ & 5.81 & 17.32 & 27.94 & 24.01 & 36.17 & 40.49 & 30.44 \\
\hline $\mathrm{SiO}_{2}$ & 2.65 & 2.09 & 5.01 & 4.53 & 3.21 & 3.69 & 2.50 \\
\hline $\mathrm{Al}_{2} \mathrm{O}_{3}$ & 6.77 & 6.04 & 5.70 & 4.31 & 4.57 & 4.10 & 6.62 \\
\hline $\mathrm{Fe}_{2} \mathrm{O}_{3}$ & 3.61 & 2.85 & 3.31 & 2.91 & 3.27 & 2.63 & 2.01 \\
\hline
\end{tabular}

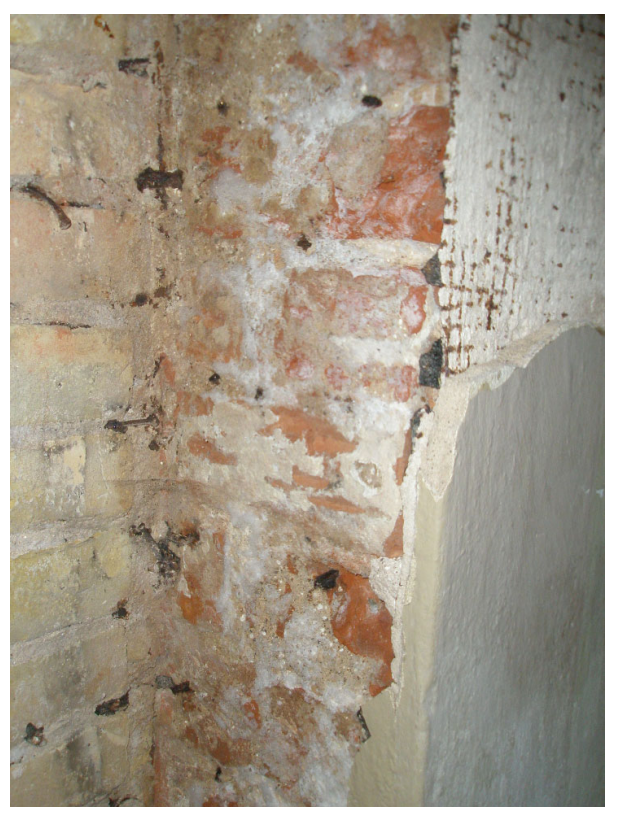

Figure 3. Efflorescence of salts on inner wall
Mortars are almost free of soluble salts, that can also be seen by their good mechanical condition. The soluble salt test showed that there is no presence of sulphates $\left(\mathrm{SO}_{4}{ }^{2-},<200 \mathrm{mg} / \mathrm{l}\right)$ in tested mortars. Nitrates were detected just in two samples (LA7 and LA10) where $\mathrm{NO}^{3-}$ concentration is $100 \mathrm{mg} / \mathrm{l}$, that do not affect the strength of mortar presently. Chlorides were detected also in two samples (LA4 and LA5), where concentration is characterized as high $\left(\mathrm{Cl}^{-}, 500 \mathrm{mg} / \mathrm{l}\right)$. Such a high content of chlorides is causing significant corrosion of mortar and the salt sources must be isolated.

The white salts on the surface of bricks on the inner wall near the entrance (left side) are $\mathrm{KNO}_{3}$ (see Figure 3 and Figure 4). This salt is formed in historic masonry mostly from the clay minerals (from bricks), and from biological processes caused by bacteria. Previous appliance of inappropriate rendering materials (dense synthetic layer) has led to efflorescence of $\mathrm{KNO}_{3}$ on the wall. The salts must be removed from the surface in dry state to avoid their possible migration back into the wall. 


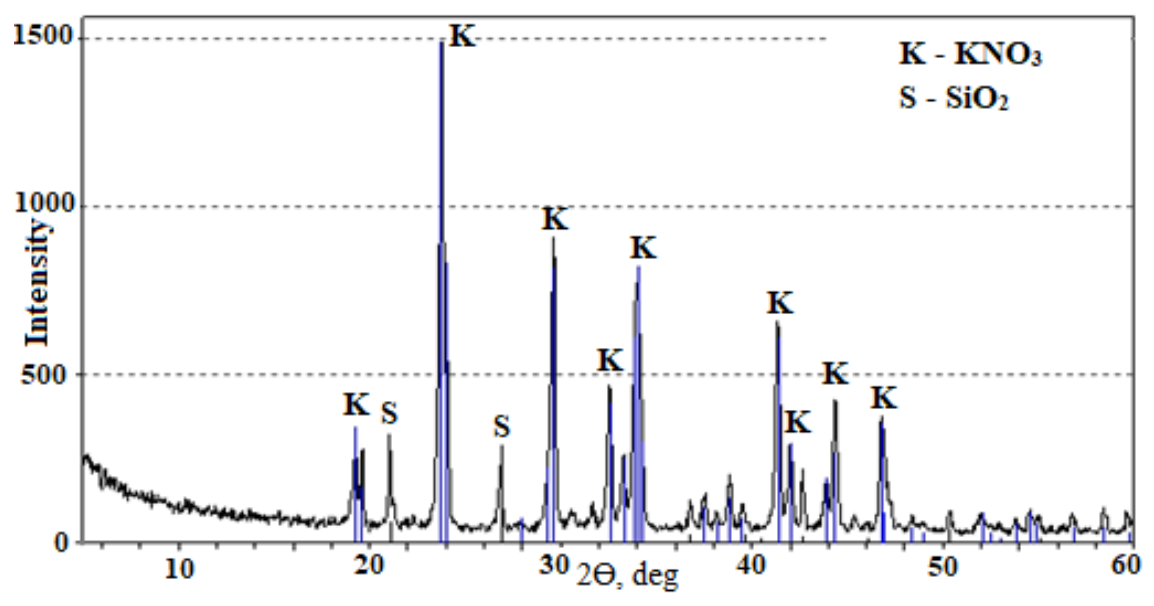

Figure 4. XRD of salts from inner wall

The SEM investigation (see Figure 5) shows a homogenous, well carbonized matrix of calcitic lime based mortar (sample LA1). On the surface of sample LA4 the salts (chlorides) were detected. The structure of dolomitic lime mortar is less homogenous, large agglomerates are present (see Figure 6).

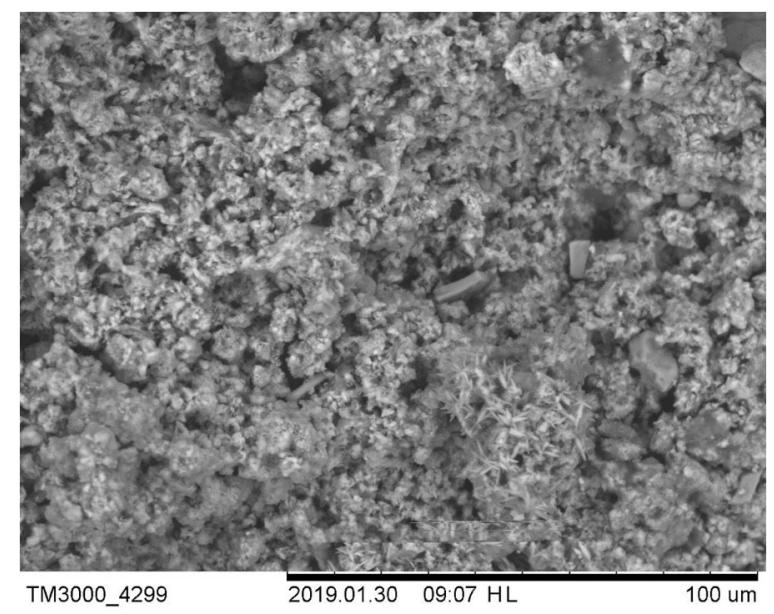

Figure 5. The SEM micrograph of mortar sample LA1 (resolution 1000x)

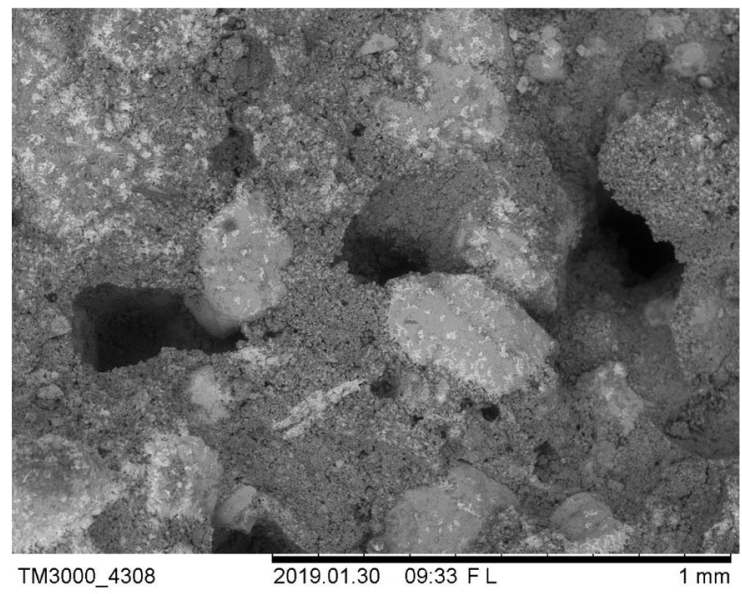

Figure 6. The SEM micrograph of mortar sample LA4 (resolution 100x) 
The apparent density of mortar samples was $1.75-1.94$, but real density was in range $2.18-2.43 \mathrm{~g} / \mathrm{cm}^{3}$, water absorption $-7.53-13.56 \%$, porosity $33-40 \%$. The granulometrical analysis showed that the basic part of filler is sand in size range $0.15-0.60 \mathrm{~mm}$ (71-93 mass \%). According to high porosity of historical material, the cement based mortars are not appropriate in this building because of their high density, low elasticity and low vapour permeability that would block the moisture migration in the walls causing damage risk (van Hees, Binda, Papayianni, \& Toumbakari, 2004).

\section{Conclusions}

The binding material of original mortars used for rendering and cladding of the walls of St. John's Church in Cesis were characterized and found to be weakly hydraulic dolomitic and calcitic lime-based mortars mixed with brick dust and fine sand.

To stop the transport of soluble $\mathrm{KNO}_{3}$ in the walls, the moisture migration must be limited by constructing ventilation cannals near the outer walls of the church, that would provide free moisture exchange. The crystallized salts must be removed from the inner surfaces and utilized, to prevent migration back into the masonry.

Usage of compatible materials is essential factor to provide longevity of historic monuments. Dolomitic and calcitic lime with brick dust additive with binder to sand ratio approx. 1:3 could be proposed as optimal choice as restoration material for the historic mortars.

\section{References}

Ashurst, J. (1988) Practical building conservation: English Heritage technical handbook (vol. 3 Mortars, Plasters and Renders). English Heritage: Hants.

Černý, R., Kunca, A., Tydlitát, V., Drchalová, J., \& Rovnaníková, P. (2006). Effect of pozzolanic admixtures on mechanical, thermal and hygric properties of lime plasters. Construction and Building Materials, 20(10), 849-857. https://doi.org/10.1016/j.conbuildmat.2005.07.002

Divet, L. (2010). La chaux. Troyes.

Dzene, L. (2011). The effect of brick dust additive to the properties of lime mortar (Bachelor's Thesis). Riga Technical University, Latvia.

Idir, R., Cyr, M., \& Tagnit-Hamou, A. (2011). Pozzolanic properties of fine and coarse color-mixed glass cullet. Cement and Concrete Composites, 33(1), 19-29. https://doi.org/10.1016/j.cemconcomp.2010.09.013

Kiriloviča, I., Gulbe, L., Vītiņa, I., \& Igaune-Blumberga, S. (2015). Chemical characterization of lime-based binders in historic buildings of Latvia. IOP Conference Series: Materials Science and Engineering, 96(1), 1-10. https://doi.org/10.1088/1757-899X/96/1/012074

Krage, L., \& Vitina, I. (2005). Research of binders in historical buildings in Latvia: A brief description of the current situation. In Proceedings of $7^{\text {th }}$ Triennal Meeting for Restorers' of the Baltic States (pp. 204-209). Riga, Latvia.

Nežerka, V., Slížková, Z., Tesárek, P., Plachý, T., Frankeová, D., \& Petráňová, V. (2014). Comprehensive study on mechanical properties of lime-based pastes with additions of metakaolin and brick dust. Cement and Concrete Research, 64, 17-29. https://doi.org/10.1016/j.cemconres.2014.06.006

Pacheco-Torgal, F., Faria, J., \& Jalali, S. (2012). Some considerations about the use of lime-cement mortars for building conservation purposes in Portugal: A reprehensible option or a lesser evil?, Construction and Building Materials, 30, 488494. https://doi.org/10.1016/j.conbuildmat.2011.12.003

Palomo, A., Blanco-Varela, M. T., Martinez-Ramirez, S., Puertas, F., \& Fortes, C. (2004). Hitoric mortars: characterization and durability. New tendencies for research. European research on cultural heritage. In ARCCHIP European Research on Cultural Heritage. State-of-the-Art studies, 3, 167-184.

Teutonico, J. M. (1988). A Laboratory manual for architectural conservators. ICCROM, Rome.

Teutonico, J. M., McCaig, I., Burns, C., \& Ashurst, J. (1993). The smeaton project: Factors affecting the lime-based mortars. APT Bulletin: The Journal of Preservation Technology, 25(3/4), 32-49. https://doi.org/10.2307/1504464

van Hees, R. P. J., Binda, L., Papayianni, I., \& Toumbakari, E. (2004). Damage analysis as a step towards compatible repair mortars. In C. Groot, G. Ashall, \& J. Hughes (Eds.), Characterisation of old mortars with respect to their repair - State-ofthe-art report of RILEM Technical Committee 167-COM (Chaper 3, pp. 105-152). RILEM Publications. 